\title{
Evaluation of seasonality in the diagnosis of diffuse large B cell lymphoma in Turkey
}

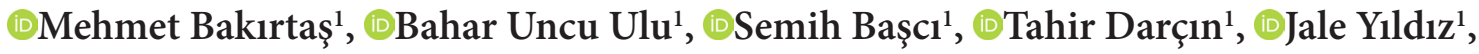

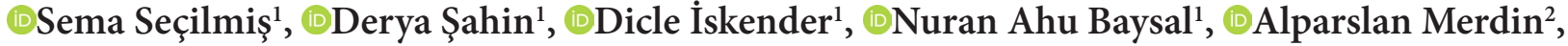

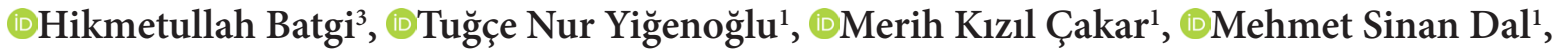 \\ (DFevzi Altuntaş ${ }^{1}$ \\ ${ }^{1}$ University of Health Sciences, Ankara Dr. Abdurrahman Yurtaslan Oncology Training and Research Hospital, Department of Hematology \\ and Bone Marrow Transplantation Center, Ankara, Turkey \\ ${ }^{2}$ University of Health Sciences, Gülhane Training and Research Hospital, Department of Hematology and Bone Marrow Transplantation \\ Center, Ankara, Turkey \\ ${ }^{3}$ University of Health Sciences, Ankara Training and Research Hospital, Department of Hematology, Ankara, Turkey
}

Cite this article as: Bakırtaş M, Uncu Ulu B, Başc1 S, et al. Evaluation of seasonality in the diagnosis of diffuse large B cell lymphoma in Turkey. J Health Sci Med 2021; 4(2): 123-126.

\begin{abstract}
Introduction: Within subtypes of non-Hodgkin lymphoma (NHL), diffuse large B cell lymphoma (DLBCL) is most commonly diagnosed, with an incidence of 6/100.000 in Turkey. Aetiology of DLBCL is unknown: several factors such as immunosuppression, AIDS, transplantation, autoimmunity, UV radiation, pesticides, hair dyes and dietary intake are hypothesized to be related with increased risk. Here, we aimed to determine the relationship between the diagnosis time of DLBCL and seasons.

Material and Method: A total of 369 DLBCL patients, diagnosed in our centre were included in the study. Data related to gender, age and time of diagnosis were analysed retrospectively.

Results: Median age of patients with DLBCL included in the study was 61 (range 16-81). The number of female patients were $178(48.2 \%)$ and 191 (51.8\%) were male. There was no relationship between the season of diagnosis time and DLBCL incidence (p:0,805).

Conclusion: According to our literature review, this is the first study that sort for a relationship between DLBCL diagnosis frequency and seasons in Turkey. We could not find a relationship between diagnosis time of DLBCL and seasons. This can be explained by the fact that the diagnosis of DLBCL displays a homogeneous distribution throughout the year due to a number of factors playing roles in the ethiopathogenesis of DLBCL.
\end{abstract}

Keywords: Non-Hodgkin lymphoma, diffuse large B cell lymphoma, seasonality

\section{INTRODUCTION}

Within subtypes of non-Hodgkin lymphoma (NHL), diffuse large B cell lymphoma (DLBCL) is most commonly diagnosed, with an incidence of 6/100.000 in Turkey $(1,2)$. Most of the patients with DLBCL are over the age of 60 years, men are more frequently affected than women $(3,4)$. Aetiology of DLBCL is unknown: several factors such as immunosuppression, AIDS, transplantation, autoimmunity, UV radiation, pesticides, hair dyes and dietary intake are hypothesized to be related with increased risk (5). Primary central nervous system lymphoma is highly associated with Epstein-Barr virus (EBV) (6). Vitamin D has an important role in immune system functioning and can act as an anti-proliferative in various haematological cancers $(7,8)$. Other factors associated with sunlight exposure may also reduce prostate cancer and NHL risk. Sunlight exposure modulates subclinical both local and systemic inflammation on a cellular basis (12). Serum levels of the vitamin $\mathrm{D}$ is season dependant, dietary intake and vacations in sunny regions are main factors (13-15). Turkey is located between $36^{\circ}-42^{\circ}$ North parallels and $26^{\circ}-45^{\circ}$ East meridians. Months between December to February are winter; March to May are spring, June to August are summer and September to November are the autumn months $(16,17)$. 
Although several studies aimed to show the effect of between sunlight and lymphoma or solid tumours; data regarding seasonal variation of DLBCL diagnosis is scarce (18-20). Since vitamin D modulates proliferation and differentiation of cancer cells, we aimed to determine the relationship between the diagnosis time of DLBCL and seasons.

\section{MATERIAL AND METHOD}

The study was approved by Health Sciences University, Ankara Dr. Abdurrahman Yurtaslan Oncology Training and Research Hospital, Clinical Researches Ethics Committee (decision no: 2020-06/677; date: 24.06.2020). All procedures were performed adhered to the ethical rules and the Helsinki Declaration of Principles.

A total of 369 DLBCL patients, diagnosed in our centre were included in the study. Data related to gender, age and time of diagnosis were analysed retrospectively. Patients over 18 years of age who were diagnosed with DLBCL by examining tissue biopsy by immune histochemical analysis were included in the study. Patients who were diagnosed in another centre or those whose diagnosis date could not be reached were not included in the study.

Data analysis was performed using IBMSPSS v26 software. Descriptive statistics were utilized to summarize data. Categorical data were presented as number-percentages, and numerical data were presented as median, minimum, and maximum. Differences between categorical variables were analysed with Chi-Square tests. A p value of $\leq 0.05$ was considered statistically significant. The study was approved by the local ethics committee.

\section{RESULTS}

Median age of patients with DLBCL included in the study was 61 (range 16-81). The number of female patients were 178 (48.2\%) and 191 (51.8\%) were male. The months when patients were diagnosed with DLBCL are shown in Table 1, and seasons are shown in Table 2. There was no relationship between the season of diagnosis time and DLBCL incidence $(\mathrm{p}=0.805)$.

\section{DISCUSSION}

In the majority of patients, the aetiology of DLBCL is unknown. Analysing seasonal differences of incidence can improve understanding of pathogenesis and risk factors of different diseases. Hodgkin's disease and Burkitt's lymphoma have been associated with EBV. Because of this infectious aetiology, researchers investigated to find out the relationship between the diagnosis time and seasons $(21,22)$. Some previous
Table 1. The distribution of diffuse large B cell lymphoma diagnosis times

\begin{tabular}{|lcc|}
\hline Months & DLBCL (n, \%) & p value \\
\hline January & $24(6.5 \%)$ & \\
February & $23(6.2 \%)$ & \\
March & $40(10.8 \%)$ & \\
April & $26(7 \%)$ & \\
May & $30(8.1 \%)$ & \\
June & $29(7.8 \%)$ & \\
July & $34(9.2 \%)$ & \\
August & $28(7.6 \%)$ & \\
September & $26(7 \%)$ & \\
October & $32(8.6 \%)$ & \\
November & $39(10.5 \%)$ & \\
December & $38(10.5 \%)$ & \\
Total & $369(100 \%)$ & \\
\hline DLBCL, diffuse large B cell lymphoma & \\
\hline
\end{tabular}

Table 2. The distribution of diffuse large B cell lymphoma diagnosis times

\begin{tabular}{|lcc|}
\hline Seasons & DLBCL (n, \%) & p value \\
\hline Winter & $85(23.2 \%)$ & \\
Spring & $96(25.9 \%)$ & \\
Summer & $91(24.6 \%)$ & $\mathrm{p}=0.805$ \\
Autumn & $97(26.2 \%)$ & \\
Total & $369(100 \%)$ & \\
\hline DLBCL, diffuse large B cell lymphoma & \\
\hline
\end{tabular}

reports have shown significant seasonal differences in Burkitt's lymphoma diagnosis, based on the time of the first symptom (23-25). However, other studies have found no relation between seasons and Hodgkin's disease and Burkitt's lymphoma. In addition, other previous studies have reported Burkitt's lymphoma endemicity to coincide with rainfall, low altitude, as well as malaria endemicity (26-30). It has been postulated that an increase in the incidence of Burkitt's lymphoma seen during the rainy seasons may be due to increased mosquitoes that breed during the season, yet they are vectors for EBV. Furthermore, the rainy seasons also come with an increase in malaria infections, which is suspected to compromise the immunity, leading to increased susceptibility to Burkitt's lymphoma $(31,32)$. Williams et al. (33) and Oguonu et al. (34) reported a higher but not statistically significant difference in prevalence of Burkitt's lymphoma in the dry season as compared to the wet season, in Uganda and Nigeria, respectively. Researchers had previously observed a significantly higher occurrence of Burkitt's lymphoma in the wet season as compared to the dry one in South Africa and Malawi, respectively $(32,35)$. Similarly, a seasonal variation is demonstrated in HL; a peak around March and a drop around September in the northern hemisphere is observed (36). Moreover, Porojnicu 
et al. (37) defined season of diagnosis as a prognostic factor in HL, where a lower case fatality was observed during autumn, which may be due to a higher serum level of vitamin $\mathrm{D}$. In a recent review by van der Rhee et al. (38) it was stated that epidemiological data suggests chronic but not intermittent sun exposure is associated with a reduced risk of colorectal, breast, prostate cancer and NHL, however, higher vitamin D levels were only associated with a reduced risk of colorectal and breast cancer. Low serum 25-hydroxyvitamin levels were not associated with the overall risk of lymphoid cancer in two prospective studies $(39,40)$; as well as Cohort Consortium Vitamin D Pooling Project of Rarer Cancer failed to show an elevated vitamin $\mathrm{D}$ level is associated with a reduced risk of NHL (41). Soni et al. (42) demonstrated an inverse association between sun exposure and risk of DLBCL. However, Swedish Lymphoma Register study failed to show a significant change in cases diagnosed per month (43). In our study, we could not demonstrate any significant seasonal variation of DLBCL diagnosis.

\section{CONCLUSION}

There are limited number of studies about the relationship between DLBCL and seasons. Among the studies examining this relationship in various geographical regions of the world, some studies found a relationship between lymphoma diagnosis frequency and seasons, whereas some other did not reveal such a relationship. According to our literature review, this is the first study that sort for a relationship between DLBCL diagnosis frequency and seasons in Turkey. We could not find a relationship between diagnosis time of DLBCL and seasons. This can be explained by the fact that the diagnosis of DLBCL displays a homogeneous distribution throughout the year due to a number of factors playing roles in the ethiopathogenesis of DLBCL.

\section{ETHICAL DECLARATIONS}

Ethics Committee Approval: The study was approved by Health Sciences University, Ankara Dr. Abdurrahman Yurtaslan Oncology Training and Research Hospital, Clinical Researches Ethics Committee (decision no: 2020-06/677; date: 24.06.2020).

Informed Consent: Because the study was designed retrospectively, no written informed consent form was obtained from patients.

Referee Evaluation Process: Externally peer-reviewed.

Conflict of Interest Statement: The authors have no conflicts of interest to declare.

Financial Disclosure: The authors declared that this study has received no financial support.
Author Contributions: All of the authors declare that they have all participated in the design, execution, and analysis of the paper, and that they have approved the final version.

\section{REFERENCES}

1. Swerdlow SH, Campo E, Pileri SA, et al. The 2016 revision of the World Health Organization classification of lymphoid neoplasms. Blood 2016; 127: 2375-90.

2. Republic of Turkey. Ministry of Health. Ankara: Ministry of Health 2014 Statistics.

3. Morton LM, Wang SS, Devesa SS, Hartge P, Weisenburger DD, Linet MS. Lymphoma incidence patterns by WHO subtype in the United States, 1992-2001. Blood 2006; 107: 265-76.

4. Hartge P, Devesa SS. Quantification of the impact of known risk factors on time trends in non-Hodgkin's lymphoma incidence. Cancer Res 1992; 52; 5566s-9s.

5. Blinder V, Fisher SG. Lymphoma Research Foundation, New York. The role of environmental factors in the etiology of lymphoma. Cancer Invest 2008; 26: 306-16.

6. Fisher SG, Fisher RI. The emerging concept of antigen-driven lymphomas: epidemiology and treatment implications. Curr Opin Oncol 2006; 18: 417-24.

7. Hall AC, Juckett MB. Te role of vitamin D in hematologic disease and stem cell transplantation. Nutrients 2013; 5: 2206-21.

8. Baeke F, Takiishi T, Korf H, Gysemans C, Mathieu C. Vitamin D: modulator of the immune system. Curr Opin Pharmacol 2010; 10: 482-96.

9. Norval M, McLoone P, Lesiak A, Narbutt J. The effect of chronic ultraviolet radiation on the human immune system. Photochem Photobiol 2008; 84: 19-28.

10.Zhu Y, Leaderer D, Guss C, et al. Ala394Thr polymorphism in the clock gene NPAS2: a circadian modifier for the risk of nonHodgkin's lymphoma. Int J Cancer 2007; 120: 432-5.

11. Steindal AH, Porojnicu AC, Moan J. Is the seasonal variation in cancer prognosis caused by sun-induced folate degradation? Med Hypotheses 2007; 69: 182-5.

12. Hersey P, Bradley M, Hasic E, Haran G, Edwards A, McCarthy WH. Immunological effects of solarium exposure. Lancet 1983; 1: 545-8.

13.Zehnder D, Bland R, Williams MC, et al. Extrarenal expression of 25-hydroxyvitamin D (3) 1 Alpha-hydroxylase. J Clin Endocrinol Metab 2001; 86: 888-94.

14.Zittermann A. Vitamin D in preventive medicine: are we ignoring the evidence? Br J Nutr 2003; 89: 552-72.

15. Burgaz A, Akesson A, Oster A, Michaëlsson K, Wolk A. Associations of diet, supplement use, and ultraviolet $\mathrm{B}$ radiation exposure with vitamin D status in Swedish women during winter. Am J Clin Nutr 2007; 86: 1399-404.

16. Koçman A. Climate in Turkey. İzmir: Ege University Faculty of Sciece and Letters Publications 1993.

17. Yalki H. Investigation of solar and wind energy potential in Turkey and the utilization of this energy. Yildiz Tech Univ Istanb 2007; III: 1-47. Machine Design.

18. Adami J, Gridley G, Nyrén O, et al. Sunlight and non-Hodgkin's lymphoma: a population-based cohort study in Sweden. Int J Cancer 1999; 80: 641-5.

19. Veierød MB, Smedby KE, Lund E, Adami HO, Weiderpass E. Pigmentary characteristics, UV radiation exposure, and risk of non-Hodgkin lymphoma: a prospective study among Scandinavian women. Cancer Epidemiol Biomarkers Prev 2010; 19: 1569-76.

20.van der Rhee HJ, de Vries E, Coebergh JW. Does sunlight prevent cancer? A systematic review. Eur J Cancer 2006; 42: 2222-32. 
21.Brooks LA, Crook T, Crawford DH. Epstein-Barr virus and lymphomas. Cancer Surv 1998; 33: 123.

22.Carpenter LM, Newton R, Casabonne D, et al.Antibodies against malaria and Epstein-Barr virus in childhood Burkitt lymphoma: A case-control study in Uganda. Int J Cancer 2008; 122: 1319-23.

23. Burkitt D, Wright $\mathrm{D}$. Geographical and tribal distribution of the African lymphoma in Uganda. Br Med J 1966; 1: 569-73.

24.Karimi M, Yarmohammadi H. Seasonal variations in the onset of childhood leukemia/lymphoma: April 1996 to March 2000, Shiraz, Iran. Hematol Oncol 2003; 21: 51-5.

25.Van den Bosch C, Lloyd G. Chikungunya fever as a risk factor for endemic Burkitt's lymphoma in Malawi. Trans R Soc Trop Med Hyg 2000; 94: 704-5.

26. Morrow RH, Pike MC, Smith PG. Further studies of spacetime clustering of Burkitt's lymphoma in Uganda. Br J Cancer 1977; 35: $668-73$

27.Siemiatycki J, Brubaker G, Geser A. Space-time clustering of Burkitt's lymphoma in East Africa: analysis of recent data and a new look at old data. Int J Cancer 1980; 25: 197-203.

28. Newell RG, Cabanillas GF, Hagemeister JF, Butler JJ. Incidence of lymphoma in the US Classified by the Working Formulation. Cancer 1987; 59: 857-61.

29. Makata AM, Toriyama K, Kamidigo NO, Eto H, Itakura H. The pattern of pediatric solid malignant tumors in Western Kenya, East Africa, 1979-1994: an analysis based on histopathologic study. Am J Trop Med Hyg 1996; 54: 343-7.

30.Parkin DM, Sohier R, O'Conor GT. Geographic distribution of Burkitt'slymphoma, In: Lenoir G, O'Conor G, Olweny CL, editors. Burkitt's lymphoma: A human cancer model. Lyon: IARC 1985. p. 155-64.

31. Mutalima N, Molyneux E, Jaffe $\mathrm{H}$, et al. Associations between Burkitt lymphoma among children in Malawi and Infection with HIV, EBV and Malaria: results from a Case-Control Study. PLoS ONE 2008; 3: e2505.

32.Hesseling P, Wood RE, Nortjé CJ, Mouton S. African Burkitt's lymphoma in the Cape Province of South Africa and in Namibia. Oral Surg Oral Med Oral Pathol 1989; 68: 162-6.

33. Williams EH, Day NE, Geser AG. Seasonal variation in onset of Burkitt's lymphoma in the West Nile district of Uganda. Lancet 1974; 2: 19-22.

34.Oguonu T, Emodi I, Kaine W. Epidemiology of Burkitt's lymphoma in Enugu, Nigeria. Ann Trop Paediatr 2002; 22: 36974

35. Van Den Bosch C, Hills M, Kazembe P, Dziweni C, Kadzamira L. Time-space case clustering of Burkitt's lymphoma in Malawi. Leukemia 1993; 7: 1875-8.

36.Borchmann S, Müller H, Engert A. Hodgkin Lymphoma has a seasonal pattern of incidence and mortality that depends on latitude. Sci Rep 2017; 7: 14903.

37.Porojnicu AC, Robsahm TE, Ree AH, Moan J. Season of diagnosis is a prognostic factor in Hodgkin's lymphoma: a possible role of sun-induced vitamin D. Br J Cancer 2005; 93: 571-4.

38.van der Rhee H, Coebergh JW, de Vries E. Is prevention of cancer by sun exposure more than just the effect of vitamin $\mathrm{D}$ ? A systematic review of epidemiological studies. Eur J Cancer 2013; 49: 1422-36.

39. Lim U, Freedman DM, Hollis BW, et al. A prospective investigation of serum 25- hydroxyvitamin $\mathrm{D}$ and risk of lymphoid cancers. Int J Cancer 2009; 124: 979-86.

40.Łuczyńska A, Kaaks R, Rohrmann S, et al. Plasma 25-hydroxyvitamin D concentration and lymphoma risk: results of the European Prospective Investigation into Cancer and Nutrition. Am J Clin Nutr 2013; 98: 827-38.
41.Purdue MP, Freedman DM, Gapstur SM, et al. Circulating 25-hydroxyvitamin D and risk of non-Hodgkin lymphoma: cohort consortium vitamin $\mathrm{D}$ pooling project of rarer cancers. Am J Epidemiol 2010; 172: 58-69.

42. Soni LK, Hou L, Gapstur SM, Evens AM, Weisenburger DD, Chiu BC. Sun exposure and non-Hodgkin lymphoma: A populationbased, case-control study. Eur J Cancer 2007; 43: 2388-95.

43.Székely E, Lindén O, Peterson S, Jerkeman M. Season of diagnosis is associated with overall survival in patients with diffuse large B-cell lymphoma but not with Hodgkin's lymphoma - A population-based Swedish Lymphoma Register study. Eur J Haematol 2016; 97: 393-8. 